\title{
Plasma Antioxidant Changes after Acute Cadmium Intoxication in Rats
}

\author{
E. HIJOVÁ, F. NIŠTIAR* \\ Institute of Experimental Medicine, *Department of Pathological Physiology, \\ Medical Faculty, P.J. Šafárik University, Košice, Slovak Republic \\ Received February 9, 2005 \\ Accepted November 10, 2005
}

\begin{abstract}
Hijová E., F. Ništiar: Plasma Antioxidant Changes after Acute Cadmium Intoxication in Rats. Acta Vet Brno 2005, 74: 565-569.

Cadmium $(\mathrm{Cd})$ is one of the most widespread environmental and occupational pollutants. The effects of acute cadmium exposure on indicators of antioxidant status was investigated in male and female Wistar albino rats. Administration of cadmium in single lethal dose $\mathrm{LD}_{50}$ of $\mathrm{CdCl}_{2}$ or in this dose divided into three equal doses significantly $(p<0.001)$ decreased of plasma total antioxidant status. The concentration of vitamin E was also significantly reduced $(p<0.001)$. Similar tendency had concentration of uric acid. The mild non-significant decreased was concentration of vitamin $C$. The changes in concentrations of vitamin A copy the changes of zinc in blood plasma. The acute exposure to Cd significantly $(p<0.001)$ increased the content of cadmium a zinc in the rats liver. These results show that acute cadmium intoxication has an unfavourable effect on plasma antioxidant status in rats caused consumption of extracellular antioxidants.
\end{abstract}

Cadmium chloride, plasma total antioxidant status, vitamin $C$, vitamin $E$, vitamin A, zinc, uric acid, rats

Cadmium $(\mathrm{Cd})$ as a highly toxic metal, still attracts an attention because it is often detected in the air, water and food product extending the maximum allowable limits (Korének ová et al. 2002; Eklund and Oskarss on 1999). Exposure to cadmium can cause a variety of adverse health effects although the mechanisms of cadmium toxicity are not fully understood.

Cadmium has an extremely long half time (20 - 30 years) in the human body and is highly cumulative, especially in the liver and kidney. It is well established that $\mathrm{Cd}$ is bound to the sulfhydryl (-SH) groups of proteins. It can affect various metabolic processes, especially energy metabolism, membrane transport and protein synthesis (Patra et al. 1999) and may act on DNA directly or indirectly by interference with genetic control and repair mechanisms (Beyersmann and Hechtenberg 1997). Cadmium induced toxicity is implicated in generation of reactive oxygen species (ROS) and exhaustion of antioxidants (Stohs and Bagchi 1995).

The present work reports the effect of acute cadmium exposure on plasma total antioxidants status (TAS) as an integrated marker of all plasma antioxidants, and plasma concentration of individual extracellular antioxidants - vitamin C, vitamin E, vitamin A, uric acid and zinc, and content of cadmium and zinc in the rat liver.

\section{Materials and Methods}

Male and female Wistar albino rats $(\mathrm{n}=36)$, (Medical Faculty, P.J. Šafárik University, Košice, Slovak Republic) aged 99 days of average weight $285.7 \pm 48.39 \mathrm{~g}$ were housed under conventional conditions on a normal laboratory diet and supplied with drinking water. Animals were divided into three experimental groups (6 males and 6 females per group).

Group I of rats received $\mathrm{LD}_{50}$ of $\mathrm{CdCl}_{2}$ as a single dose given by a stomach tube. Group II of rats received in the same way $\mathrm{LD}_{50}$ of $\mathrm{CdCl}_{2}$ divided into three single doses $(75 \mathrm{mg} / \mathrm{kg}$ b.w. in $1 \mathrm{ml}$ solution daily) during three

Address for correspondence:

MUDr. E. Hijová

Institute of Experimental Medicine, Medical Faculty, P. J. Šafárik University, SNP 1, 04011 Košice, Slovak Republic
Phone: ++421556424606

Fax: ++421556420253

e-mail: hijova@pobox.sk

http://www.vfu.cz/acta-vet/actavet.htm 
consecutive days. Group III (controls) of rats received drinking water without $\mathrm{CdCl}_{2}$. Cadmium was given between $06 .{ }^{00}-07 .{ }^{00} \mathrm{~h}$ by stomach tube to the experimental groups (I+ II) as a cadmium chloride compound $\left(\mathrm{CdCl}_{2} .2 \mathrm{H}_{2} \mathrm{O}\right.$, Sigma) at a dose $\mathrm{LD}_{50}$ of Cd diluted in drinking water. The $\mathrm{LD}_{50}$ value of $\mathrm{Cd}$ as $\mathrm{CdCl}_{2}$ per os for rats is $225 \mathrm{mg} / \mathrm{kg}$ (Kotsonis and Klaasen 1977)). The intake of drinking water and food was controlled during experiment.

After $24 \mathrm{~h}$ (Group I) or $72 \mathrm{~h}$ (Group II) rats were anaesthetized (Sodium pentobarbitale, Pentobarbital Spofa, 50 $\mathrm{mg} / \mathrm{kg}$, i.p.) and blood samples were taken from heart by puncture using heparin (Heparinum natricum 5000 IU/l inj.) as an anticoagulant. Samples were centrifuged at $1500 \mathrm{~g}$ for $15 \mathrm{~min}$. and the plasma specimens were used for determination followed parameters.

The plasma total antioxidant status was determined by a spectrophotometric method with a RANDOX kit (Total antioxidant status, Randox laboratories, UK). The measurement was carried out on an automatic spectrophotometric analyser Cobas Mira S (Roche, Schwitzerland). The concentrations of vitamin E and vitamin A were determined by HPLC method according to Sanz-Cuesta and Santa-Cruz (1986) and of vitamin C by colorimetric method according to R oe and Kuether (1943). The plasma concentration of zinc and uric acid were measured using commercial kits (WAKO Chemicals GmbH, DE, and Pliva-Lachema, Czech Republic, respectively). The content of cadmium and zinc in the liver were analyzed using an atomic absorption spectrophotometer (Unicam Solar, 939).

The results were evaluated using Student's $t$-test and ANOVA. Statistical significance was accepted at $p<0.05$.

The experiment was conducted according to the principles provided in the Act No. 115/1995 Coll. of Slovak Republic for the Care and Use of Laboratory Animals.

\section{Results}

In the course of acute cadmium exposure 4 females and 1 male from Group I and 4 males and 2 females from Group II group died. During the whole experiment the animals were anxious, had accelerated breathing, and visible bloody discharge from nostrils and eyes. The internal organs were macroscopically enlarged and marked congested.

The intake of food and water were decreased in both group in comparison to the control group. The body weight of rats in Group I decreased significantly from the initial weight of $317.1 \pm 48.21 \mathrm{~g}$ to $296.4 \pm 47.49 \mathrm{~g}(p<0.01)$ at the end of experiment and in Group II from $265.0 \pm 48.48 \mathrm{~g}$ to $242.5 \pm 44.47 \mathrm{~g}(p<0.01)$. No significant differences in controls were observed $(275.0 \pm 46.22 \mathrm{~g}$ vs $280.0 \pm 51.52 \mathrm{~g})$.

Changes in antioxidants during acute cadmium exposure in Wistar albino rats are summarized in Table 1. The cadmium and zinc contents in the liver of rats are presented in Table 2.

Table 1. Changes in antioxidant parameters after acute cadmium exposure in rats

\begin{tabular}{|c|c|c|c|}
\hline Indices & Control group & Group I & Group II \\
\hline $\begin{array}{c}\text { TAS } \\
(\mathrm{mmol} / \mathrm{l})\end{array}$ & $1.21 \pm 0.13$ & $0.73 \pm 0.08 * * *$ & $0.93 \pm 0.11 * * *$ \\
\hline $\begin{array}{c}\text { C vitamin } \\
(\mu \mathrm{mol} / 1)\end{array}$ & $50.22 \pm 10.98$ & $39.31 \pm 13.41$ & $42.29 \pm 14.60$ \\
\hline $\begin{array}{c}\mathbf{E} \text { vitamin } \\
(\mu \mathrm{mol} / 1)\end{array}$ & $8.38 \pm 3.69$ & $3.84 \pm 0.73 * * *$ & $4.83 \pm 1.39^{* *}$ \\
\hline $\begin{array}{c}\text { A vitamin } \\
(\mu \mathrm{mol} / \mathrm{l})\end{array}$ & $1.61 \pm 0.18$ & $1.37 \pm 0.28 * *$ & $2.97 \pm 0.64 * * *$ \\
\hline $\begin{array}{c}\text { Zinc } \\
(\mu \mathrm{mol} / 1)\end{array}$ & $16.02 \pm 3.38$ & $15.92 \pm 3.21$ & $18.66 \pm 1.77 *$ \\
\hline $\begin{array}{c}\text { Uric acid } \\
(\mu \mathrm{mol} / 1)\end{array}$ & $45.0 \pm 7.93$ & $33.0 \pm 6.78 * * *$ & $36.16 \pm 9.70^{*}$ \\
\hline
\end{tabular}

Data are expressed as means \pm SD. Significant differences calculated from those in control group are designated as : ${ }^{*} p<0.05 ; * *<0.01 ; * * p<0.001$ 
Table 2. Effect of cadmium on content of cadmium and zinc in the liver

\begin{tabular}{|clcc|}
\hline Indices & Control group & Group I & Group II \\
\hline $\begin{array}{c}\text { Cadmium } \\
(\mathrm{mg} / \mathrm{kg})\end{array}$ & $0.038 \pm 0.007$ & $88.61 \pm 9.69^{* * *}$ & $154.79 \pm 40.24^{* * *}$ \\
\hline $\begin{array}{c}\text { Zinc } \\
(\mathrm{mg} / \mathrm{kg})\end{array}$ & $57.33 \pm 4.18$ & $87.50 \pm 4.54 * * *$ & $119.66 \pm 73.28^{* * *}$ \\
\hline
\end{tabular}

Data are expressed as means \pm SD. Significant differences calculated from those in control group are designated as : ${ }^{*} p<0.05 ; * * p<0.01 ; * * p<0.001$

\section{Discussion}

Environmental contamination by different agents is recognized as a world-wide problem. Various possible mechanisms have been suggested to explain the damage induced by heavy metals. Proteins are major targets of damage by metals and the loss of protein function is usually a consequence of their modification by metals. Metals have a special affinity toward (-SH) groups of proteins. By covalent binding to (-SH) groups, metals can block the functional sites of the catalytic or binding domains of enzymes, or modify protein conformation.

The second possible mechanism may be the displacement of metal, which is essential for biological activity of a molecule by another one. Most frequently, zinc-requiring enzymes are inactivated through direct displacement of zinc by another metal ion from the binding site. Transition metals are known to be able to generate extremely reactive oxygen species. A number of authors have focused their attention on the influence of chronic cadmium intoxication on activity of intracellular antioxidants, but measurements of total antioxidant status as an integrated marker of extracellular antioxidants after metal intoxications are rare. Acute exposure to cadmium can cause a variety of adverse effects for the health status. It was demonstrated that cadmium is a potent inducer of the cell oxidative stress and affect antioxidant defence potential biphasically by inhibition and enhancement of several antioxidant enzymatic and non-enzymatic molecule activity (Sarkar et al. 1998; Gupta et al. 1991).

In our experiment significantly decreased TAS $(p<0.001)$ in both groups after acute cadmium exposure could be an answer of plasma antioxidants to an elevation reactive oxygen species. Vitamin $\mathrm{C}$ and vitamin $\mathrm{E}$ together constitute only $12 \%$ of the TAS in comparison with uric acid, which constitutes 33\% of the TAS (Miller et al. 1993).

Cadmium is a nephrotoxic metal (Friberg 1948). The proximal tubules of the kidney are a major target of chronic cadmium-induced toxicity. The development of cadmium-induced lesions in the kidney is characterized by proteinuria and excessive urinary excretion of other substrates such as enzymes, amino acids, and glucose (Theven od and Friedmann 1999). Exposure of renal cells to cadmium causes apoptotic features, DNA fragmentation and chromatin condensation in earlier stages of cadmium cytotoxicity than the cadmiuminduced necrotic phase (Ishido et al. 1998). During acute cadmium intoxication the concentration of uric acid was significantly reduced in Group I $(p<0.001)$ and in Group II $(p<0.01)$. Observed hypouricaemia could be caused by a decreased uric acid synthesis or increased excretion of uric acid by kidneys.

One important antioxidant in blood plasma and tissues with a very wide spectrum of biological effect is ascorbic acid (vitamin C). Ascorbic acid is produced from the ultimate hexose precursor D-glucose. After the pathway of ascorbic acid biosynthesis had been established, it was soon revealed that in tissues of humans, monkeys and guinea pigs, there is no activity of the terminal enzyme of the pathway, L-gulono- $\gamma$-lactone oxidase (GLO), (Nishikimi and Yagi 1996). Mice, rats and rabbits synthesize vitamin C in their livers. 
Kostic et al. (1993) have observed elevated plasma concentration of ascorbate and tocopherol as a biological response to chronic cadmium chloride intoxication. During acute cadmium intoxication no significant changes of vitamin $\mathrm{C}$ were observed. It seems that changes in concentration of vitamin $\mathrm{C}$ are time dependent because in response to $\mathrm{Cd}$ intoxication the rats in Group II began more to produce vitamin $\mathrm{C}$ in comparison to rats in Group I. Contrary to their results Shukla and Chandra (1989) showed that i.p. administered cadmium $(0.4 \mathrm{mg} / \mathrm{kg} /$ day $)$ induces a significant decline in plasma tocopherol after 30 days. In our experiment, the concentration of vitamin $\mathrm{E}$ was significantly reduced in Group I $(p<0.001)$ and in Group II $(p<0.01)$.

The fact that zinc clearly plays a major role in the toxicity of cadmium may well be due to the similar chemical nature if cadmium and zinc and their common interactions within living systems. This similar chemistry, combined with the greater affinity of cadmium for various bioligands, probably allows to displace zinc in many biological processees. Zinc as an antagonist of cadmium was after $24 \mathrm{~h}$ (Group I) from application of cadmium nonsignificantly decreased but after 72 hs (Group II) its concentration was increased $(p<0.05)$.

Changes in the concentration of vitamin A copied changes in the concentration of zinc in blood plasma. Cadmium intoxication activated the $\mathrm{Zn}$ pool in organism. Very important are positively correlation between concentration of zinc in blood plasma and vitamin A $(\mathrm{r}=$ $0.84 ; p<0.01)$, between concentration of zinc in blood plasma and TAS $(\mathrm{r}=0.68 ; p<0.05)$, and between vitamin A and TAS $(\mathrm{r}=0.77 ; p<0.01)$. Zinc and vitamin A contribute to increasing concentration of TAS. Significantly decreased concentration of retinol in kidney and testis after $48 \mathrm{~h}$ cadmium intoxication was observed by Mas sanyi et al. (1999).

In Group I of rats the content of cadmium in the liver was $88.61 \mathrm{mg} / \mathrm{kg}$ that represent $39.38 \%$ from dose $\mathrm{LD}_{50}$ of $\mathrm{Cd}$. In Group II the content of cadmium in the liver was 154.79 $\mathrm{mg} / \mathrm{kg}$ that represent $68.79 \%$ from dose $\mathrm{LD}_{50}$ of $\mathrm{Cd}$. Daily cumulation of $\mathrm{Cd}$ in this group was $51.59 \mathrm{mg} / \mathrm{kg}$ that from the daily dose $(75 \mathrm{mg} / \mathrm{kg})$ is $68.79 \%$. The content of zinc in the liver was significantly increased $(p<0.001)$ in both experimental groups.

From the present results it can be concluded, that acute cadmium intoxication caused a significant reduction of the plasma total antioxidant status and individuals extracellular antioxidants in rats.

\section{Zmeny plazmatických antioxidantov spôsobené akútnou intoxikáciou kadmiom u potkanov}

Kadmium je tažký kov a stabilný polutant životného a pracovného prostredia. Neschopnost degradovat sa prírodnými procesmi spôsobuje, že sa kadmium kumuluje (geo, bio-,ekokumulácia) a môže spôsobovat akútne a chronické intoxikácie. Kadmium spôsobuje zvýšenú produkciu bioreaktívnych foriem kyslíka a iných radikálov, ktoré indukujú oxidačný stres. Je to následok toxického účinku kadmia a vyčerpania antioxidantov v organizme. Sledovali sme účinok akútnej intoxikácie kadmiom na antioxidačné parametre plazmy u potkanov oboch pohlaví kmeňa Wistar. Kadmium vo forme $\mathrm{CdCl}_{2}$ sme aplikovali v jednorázovej letálnej dávke $\mathrm{LD}_{50}(225,0 \mathrm{mg} / \mathrm{kg})$ a rovnakú dávku rozloženú na tri aplikácie ( $75 \mathrm{mg} / \mathrm{kg}$ ž.hm. denne) jednorázovej dávky v $1 \mathrm{ml}$ roztoku. Akútna intoxikácia kadmiom signifikantne $(p<0.001)$ znížila koncentráciu celkovej antioxidačnej kapacity plazmy, vitamínu E a kyseliny močovej. Koncentrácia vitamínu $\mathrm{C}$ bola znížená nesignifikantne. Tendencia zmien v koncentrácii vitamínu A kopírovala zmeny v koncentráciach zinku v krvnej plazme. Obsah kadmia a zinku v pečeni potkanov bol signifikantne zvýšený $(p<0.001)$.

Získané výsledky poukázali na nepriaznivé účinky akútnej intoxikácie kadmiom na parametre antioxidačnej ochrany. Oprava oxidačného poškodenia organizmu nemusí byt 
stále efektívna a je tažká. Ovela efektívnejšia je prevencia, t.j. minimalizovanie zdrojov tvorby volných radikálov a využitia prirodzeného efektu látok v potravinách, ktoré pôsobia antioxidačne.

\section{Acknowledgements}

This work was supported by a grant VEGA 1/8235/01 from the Grant Agency of the Ministry of Education of the Slovak Republic and the Slovak Academy of Sciences.

\section{References}

BEYERSMANN D, HECHTENBERG S 1977: Cadmium, gene regulation and cellular signaling in mammalian cells. Toxicol Appl Pharm 144: 247-261

EKLUND G, OSKARSSON A 1999: Exposure of cadmium from infant formulas and weaning foods. Food Addit Contam 16: 509-519

FRIBERG L 1948: Proteinuria and kidney injury among workmen exposed to cadmium and nickel dust. J Ind Toxicol 30: $32-36$

GUPTA S, ATHAR M, BEHARI JR, SRIVASTAVA RC 1991: Cadmium-mediated induction of cellular defence mechanism: a novel example for the development of adaptive response against a toxicant. Ind Health 29: 1-9

ISHIDO M, HOMMA S, SUZUKI T 1998: Apoptosis in rat renal proximal tubular cells induced by cadmium. J Toxicol Env Health 55: 101-112

KORÉNEKOVÁ B, SKALICKÁ M, NAD P 2002: Cadmium exposure of cattle after long-term emission from polluted area. Trace Elem Electroly 19: 97-99

KOSTIC MM, OGNJANOVIC B, DIMITRIJEVIC S, ZIKIC RV, STAJN A, ROSIC GL, ZIVKOVIC RV 1993: Cadmium-induced changes of antioxidant and metabolic status in red blood cells of rats: in vivo effects. Eur J Haematol 51: 86-92

KOTSONIS FN, KLAASEN CD 1977: Toxicity and distribution of cadmium administered to rats at sublethal doses. Toxicol Appl Pharm 41: 667-680

MASSANYI P, BARDOS L, OPPEL K, HLUCHY S, KOVACIK J, CSICSAI G, TOMAN R 1999: Distribution of cadmium in selected organs of mice: effects of cadmium on organ contents of retinoids and beta.carotene. Acta Physiol Hung 86: 99-104

MILLER NJ, RICE-EVANS C, DAVIES MJ, GOPINATHAN V, MILNER A 1993: A novel method for measuring antioxidant capacity and its application to monitoring the antioxidant status in premature neonates. Clin Sci 84: 407-412

NISHIKIMI M, YAGI K 1996: Biochemistry and molecular biology of ascorbic acid biosynthesis. Subcel Biochem 25: $17-39$

PATRA RC, SWARUP D, SENAPATI SK 1999: Effects of cadmium on lipid peroxides and superoxid dismutase in hepatic, renal and testicular tissue in rats. Vet Hum Toxicol 41: 65-67

ROE JH, KUETHER CA 1943: Determination of ascorbic acid in whole blood and urine through the 2,4dinitrophenylhydrazine derivate of dehydroascorbic acid. J Biol Chem 143: 399-406

SANZ-CUESTA D, SANTA-CRUZ M 1986: Simultaneous measurement of retinol and alpha-tocopherol in human serum by high performance liquid chromatography with ultraviolet detection. J Chromatogr 380: $140-144$

SARKAR S, YADAV P, BHATNAGAR D 1998: Lipid peroxidation damage on cadmium exposure and alterations in antioxidant system in rat erythrocytes: a study with relation in time. Biometals 11: 153-157

SHUKLA GS, CHANDRA SF 1989: Cadmium toxicity and bioantioxidants: Status of vitamin E and ascorbic acid of selected organs in rats. J Appl Toxicol 9: 119-122

STOHS SJ, BAGCHI D 1995: Oxidative mechanisms in the toxicity of metal ions. Free Radic Biol Med 18: 321336

THEVENOD F, FRIEDMANN JM 1999: Cadmium-mediated oxidative stress in kidney proximal tubule cells induces degradation of $\mathrm{Na}^{+} / \mathrm{K}^{+}$-ATPase through proteasomal and endo-/lysosomal proteolytic pathways. FEBS J 13: 1751-1761 
